TECHNICAL TRANSACTIONS 6/2018

CIVIL ENGINEERING

DOI: $10.4467 / 2353737$ XCT.18.088.8693 SUBMISSION OF THE FINAL VERSION: $15 / 05 / 2018$

\author{
Mariusz Dudek \\ Katarzyna Solecka (ksolecka@pk.edu.pl) \\ Institute of Road, Railroad and Transportation Engineering, Faculty of Civil Engineering, \\ Cracow University of Technology
}

Matthias Richter

Faculty of Business Sciences, University of Applied Sciences, Zwickau

\title{
A MULTI-CRITERIA APPRAISAL OF THE SELECTION OF MEANS OF URBAN PASSENGER TRANSPORT USING THE ELECTRE AND AHP METHODS
}

\author{
WIELOKRYTERIALNA OCENA WYBORU ŚRODKÓW MIEJSKIEGO \\ TRANSPORTU PASAŻERSKIEGO Z WYKORZYSTANIEM \\ METOD ELECTRE I AHP
}

\begin{abstract}
This article presents the main components of the multi-criteria decision making (MCDM) methodology and their application in the assessment of several public transportation solutions in a specific traffic corridor. The corridor in question is $15 \mathrm{~km}$ long and runs through the centre of Wroclaw, Poland. The analysis focused on six alternative scenarios. The following elements were taken into consideration in their design: alternative means of land transport; different types of vehicles and priorities for public transportation; location of bus and tram stops. The individual solutions were assessed based on six criteria designed to measure different aspects of the problem with the use of two alternative MCDMmethods: Electre III/IV and AHP.Computational experiments established the final ranking of transport solutions in the corridor from best to worst in terms of the analysed criteria.
\end{abstract}

Keywords: transportation corridor, public transportation, multi-criteria decision making

\section{Streszczenie}

Wartykule przedstawiono elementymetodologiiwielokryterialnegowspomagania decyzij (MCDM), a następnie możliwość zastosowania metod MCDM do oceny rozwiązań obsługi pasma zabudowy komunikacją zbiorową. Rozważany korytarz transportowy zlokalizowany jest w centrum miasta Wroclawia (korytarz o dlugości $15 \mathrm{~km}$ ). Ocenie poddano 6 wariantów rozwiązań, przy konstruowaniu których uwzględniono następujące elementy: alternatywne środki transportu (środki transportu naziemnego), różne typy pojazdów, priorytety dla transportu publicznego, lokalizację przystanków. Do oceny rozwiązań przyjęto zestaw 6 kryteriów uwzględniających różne aspekty rozważanego problemu. Zbiór wariantów oceniono dwiema metodami wielokryterialnego wspomagania decyzji (MCDM): metodą Electre III/IV oraz AHP. W wyniku przeprowadzonych eksperymentów obliczeniowych uzyskano uszeregowanie końcowe wariantów od najlepszego do najgorszego względem rozważanych kryteriów.

Slowa kluczowe: korytarz transportowy, komunikacja zbiorowa, wielokryterialne wspomaganie decyzji 


\section{Introduction}

A public transport system is a complex operational system that is available to the general public and carries fare-paying passengers by means of a variety of transportation modes (underground/metro, buses, trams, light-rail) from their origins to their destinations on fixed routes and according to a predetermined timetable $[2,3,28]$. Public transport systems are usually operated in large cities and in densely populated areas. Large cities maintain public transport systems because they often have more traffic congestion and less parking space than smaller towns. Urban transportation helps reduce the number of vehicles on the road and it is a convenient option for people travelling over relatively short distances.

The main objective of a public transport system is to provide the passengers with a high quality service. Public transport systems encompass organised forms of passenger transport that are regulated by law and utilise publicly available space and infrastructure. Public transport systems should be characterised by the following features:

- integration (between modes) and coordination,

- safety, security and reliability for passengers,

- economic efficiency and providing good value for money,

- easy access and support for economic growth,

- health and environmental sensitivity.

Public transport systems are usually managed, organised and operated by companies called public transportation operators. These companies can be classified into two main types: common carriers and contract carriers. Common carriers are usually operated by city or regional government agencies and are open to all members of the public who are willing to pay the stated fare. Common carrier systems include transport services that are run along established routes within a city or metropolitan area, allowing people to travel without using cars or other private modes of personal transport. Contract carriers are privately-run companies that provide customised transportation services, e.g. door-to-door transportation services or a specifically designed single trip to a given destination. Contract carriers are usually more expensive than common carriers but can offer a higher level of transportation service, including transporting passengers to places which are not accessible by bus or metro and/or operating at times when a common carrier service may not be scheduled.

Similar to other complex operational systems, public transport systems face a variety of different, complicated and challenging problems. The most important problems in public transport planning are: designing the most suitable transport network which meets to the needs and expectations of passengers; defining rational timetables that guarantee matching between supply, demand and sufficient fleet utilisation; assuring appropriate funding for transport infrastructure maintenance and development; fleet composition and replacement; satisfying the interests of different stakeholders, including passengers that demand high transportation standards; providing environmentally friendly solutions; assuring coordination and integration between different transportation modes; improvement of the transportation infrastructure such that it guarantees better travel conditions for disabled and elderly persons. 
Different transportation projects and solutions are focused on the elimination of and/or the allaying of the above-mentioned public transport problems. Different public transportation projects and solutions require thorough and comprehensive appraisal. In many cases, the analysed projects must be ranked and prioritised due to limited availability of financial resources. Thus, proper appraisal of public transportation projects is highly important. In this appraisal, different aspects of technical, economic, social and environmental needed to be taken into account. Interests of different stakeholders are also analysed. The authors of different publications [7, 12, 20, 22, 23] prove that appraisal of public transportation projects should involve the analysis of between eight and twenty-one parameters. The most commonly used characteristics include [11-16, 25]: punctuality, frequency, safety, comfort, accessibility, journey time and cost, regularity, waiting time, investment profitability (e.g. passenger 's time savings, lower operating costs), financial efficiency.

Many of the above-mentioned criteria are in conflict with each other and a compromise solution [27] must be found to at least partially satisfy them. In such circumstances, the methodology of MCDM constitutes a valuable methodological framework for the appraisal of alternative public transportation projects. This methodology enables the decision maker (DM) to carry out a comprehensive appraisal of the public transportation projects in which several, often conflicting points of view must be taken into account [11].

This paper presents the application of multi-criteria decision making (MCDM) methodology to the appraisal of alternative transport solutions designed for a specific traffic corridor in a medium-sized metropolitan area. The corridor is situated in the central part of the city and has a length of $15 \mathrm{~km}$. The scenarios are designed heuristically, using common sense and expert knowledge. Two alternative MCDM methods - Electre III/IV and AHP - are applied in the appraisal process.

The paper is composed of five sections. In the introduction, the background to the research is presented. Section 2 focuses on the description of the MCDM methodology which is the major methodological framework applied in the article; in this section, the applied MCDM methods are characterised. Section 3 presents the construction of scenarios. In section 4, the appraisal of scenarios is carried out; this section includes definitions of the consistent family of criteria, modelling of the decision maker's (DM) preferences and results of computational experiments. The last section is comprised of the final conclusions followed by a list of references.

\section{Multiple criteria decision making methodology}

\subsection{Definition of multiple criteria decision making}

Multi-criteria decision making is a dynamically developing field which aims at giving the decision maker some tools in order to enable him/her to advance in solving complex decision problems, where several - often contradictory - points of view must be taken into account [27]. In contrast to the classical techniques of operations research, multi-criteria methods do not yield the 'objectively best' solutions, because it is impossible to generate such solutions which are simultaneously the best from all points of view [29]. 
The multi-objective decision problem is a situation in which having defined a set of actions/scenarios/solutions $A$ and a consistent family of criteria $F$, the DM tends to [27]:

- define a subset of $A$ which is the best with respect to $F$ (choice problem),

- divide a set of $A$ according to certain norms (sorting problem),

- rank actions/scenarios/solutions/variants in $A$ from best to worst, according to $F$ (ranking problem).

The main attributes of multi-criteria decision problems are the set of action/scenarios/ solutions/variants $A$ and a consistent family of criteria $F$. The set of action $A$ is a set of decision objectives, candidates, scenarios or actions which is analysed and appraised as part of the decision making procedure. The set of $A$ can be defined directly in the form of a complete list or indirectly in the form of certain rules and formulas that determine feasible actions/ scenarios/solutions/variants, e.g. in the form of constraints. The consistent family criteria $F$ should be characterised by the following features [19]: it should provide a comprehensive and complete appraisal of $A$; each criterion in $A$ should have a specific direction of preferences (minimized - min or maximized - max) and should not be related to other criteria in $F$. The domain of each criterion in $F$ should be disjoint with the domains of other criteria.

The MCDM methodology clearly identifies the major participants of the decision making process, such as the DM and the analyst, and describes their roles in this process. The DM (an individual or a group of individuals) defines the objectives of the decision process, expresses preferences and then evaluates the generated results. Finally, s/he selects the best solution, which is the most desirable scenario. The analyst, who is an external person in the decision making process. Their role is to construct a decision model and select the most appropriate tool to solve the decision problem. The analyst explains the consequences of certain actions to the $\mathrm{DM}$ and then recommends the most desirable action.

In accordance with $[19,27]$, MCDM methods are usually classified as:

- methods of American inspiration, based on the utility function (e.g. AHP [21], UTA [9]) that aggregate different criteria (points of view) into one global criterion called the utility function - these methods eliminate incomparability between scenarios,

- methods of the European (France) inspiration based on the outranking relation (e.g. ELECTRE III/IV methods [1, 18], Promethee I and II [1]), Oreste ([17]) that take into account the incomparability between scenarios,

- interactive methods (e.g. GDF [6], SWT ([8]), Steuer ([26]) that are based on the 'trial and error' approach in each iteration of the solution search procedure and characterised by phases of computation alternating with phases of decision making.

Multi-criteria decision making is characterised by methods that support planning and decision processes through collecting, storing and processing different kinds of information and constructing a viable idea of how to solve a multi-criteria decision problem.

The decision process for a multiple criteria problem is described by the following distinct phases:

- definition and construction of the problem (scenarios),

- definition of a set of consistent family of criteria, 
- identification of the preference system of the decision maker,

- selection of the multi-criteria method appraisal,

- computational experiment,

- analysis and comparison of results,

- choice of the best solution and conclusion.

In this paper, two multiple objective ranking methods of MCDM (ELECTRE III/IV and AHP) are applied to evaluate alternative transportation solutions (scenarios) for a specific transportation corridor. The corridor is located in a medium sized metropolitan area, in the city of Wroclaw, Poland. It stretches from the north-western to the south-eastern boundary of the city and connects the housing estates of Kozanów and Jagodno. The corridor is $15 \mathrm{~km}$ long and $1 \mathrm{~km}$ wide - it passes through the Popowice housing estate, the central railway station in Wroclaw and the Krzyki residential area. Different transportation modes, including trams and buses, operate along this corridor. For the purposes of calculation, it was assumed that the average journey distance for public transport in Wrockaw is $5 \mathrm{~km}$ and the average mobility in a working day is around 0.7 journeys per resident per day (this assumption is based on [5]). The maximum passenger flow was assumed at 20,000 passengers for an average $5 \mathrm{~km}$ journey.

\subsection{Electre III/IV method}

The ELECTRE III/IV method belongs to the family of ELECTRE methods proposed by Roy [18] and it is based on the binary outranking relation [24, 28]. In this method, the basic set of data is comprised of the following elements: a finite set of scenarios $A$; a family of criteria $F$; preferential information submitted by the DM. The preferential information is defined in the form of criteria weights $-w$, indifference $-q$, preference $-p$ and veto $-v$ thresholds [24]. Scenarios $\mathrm{a}$ and $\mathrm{b}$ are considered to be indifferent if the difference between their appraisals $f(a)$ and $f(b)$ on a specific criterion is so small (smaller than $q$ ) that the DM cannot make any distinction between scenarios. Scenario $a$ is only slightly preferable to scenario $b$ if the difference between their appraisals $f(a)$ and $f(b)$ on a specific criterion is noticeable to the $\mathrm{DM}$ (between $q$ and $p$ ) but $\mathrm{s} / \mathrm{he}$ is reluctant to prefer one scenario over the other. Scenario $a$ is strongly preferred over scenario $b$ if the difference between their appraisals $f(a)$ and $f(b)$ on $a$ specific criterion is substantial to the DM (between $p$ and $v$ ) and $\mathrm{s} /$ he is convinced that $a$ is preferable to $b$. Scenarios $a$ and $b$ are incomparable if the difference between their appraisals $f(a)$ and $f(b)$ on a specific criterion is so large (larger than $v$ ) that the DM cannot consider them as comparable objects.

The outranking relation in the ELECTRE III/IV method is built on the basis of the so-called concordance and discordance tests. In the concordance test, a concordance matrix is constructed composed of the global concordance indicators $C(a, b)$. In the discordance test, a discordance index $D j(a, b)$ is calculated for each criterion $j$. The outranking relation indicates the extent to which a outranks $b$ overall. This relation is expressed by the degree of credibility $d(a, b)$, which is equivalent to the global concordance indicator $C(a, b)$ weakened by the discordance indexes $D j(a, b)$. The values of $d(a, b)$ are from the interval [0,1]. Credibility $d(a, b)=1$ if, and only if, the assertion $a S b$ (a outranks $b$ ) is well founded, $d(a, b)=0$ if there 
is no argument in favour of $a S b$ (not $a S b-a$ does not outrank $b$ ). The definition of $d(a, b)$ results in the construction of a credibility matrix based on which the method establishes two preliminary rankings (complete pre-orders) using a classification algorithm (distillation procedure). During this procedure, one can obtain a descending and an ascending pre-order. In the descending distillation, the ranking process starts with the selection of the best scenario, which is placed at the top of the ranking. In the ascending distillation, the scenarios are ranked in the inverse order. The final ranking is generated as an intersection of the above-mentioned complete pre-orders - this can be presented either in the form of the ranking matrix or in the form of the outranking graph. The following situations in terms of the relation between variants can be distinguished there: indifference $(I)$, preference $(P)$, lack of preference $\left(P_{-}\right)$ and incomparability $(R)$. The method details, described using algorithm flowcharts, formal formulae with equation numbering, were presented in the literature by Vincke, P. [27].

\subsection{AHP method - Analytic Hierarchy Process}

The AHP (Analytic Hierarchy Process) method is a multiple objective ranking procedure proposed by T. Saaty [21] which is focused on the hierarchical analysis of the decision problem. The method is based on the multi-attribute utility theory [10] and allows the ranking of a finite set of scenarios A. Through the definition of the overall objective, appraisal criteria, sub-criteria and scenarios, the method constructs the hierarchy of the decision problem. On each level of the hierarchy, the DM's preferential information is defined in the form of relative weights $w_{a}$ based on the pair-wise comparisons of criteria, sub-criteria and scenarios [21]. Each weight represents the relative strength of the compared element against another and is expressed as a number from 1 to 9 . All weights have a compensatory character, i.e. the value characterising the less important element $(1 / 2,1 / 5,1 / 9)$ is the inverse of the value characterising the more important element in the compared pair $(2,5,9)$.

The algorithm of the AHP method focuses on finding a solution for a the so-called eigenvalue problem [21] on each level of the hierarchy. As a result, a set of vectors containing normalised, absolute values of weights $w_{a}$ for criteria, sub-criteria and scenarios is generated. The sum of the elements of the vector is $1(100 \%)$. The absolute weights $w_{a}$ are aggregated by an additive utility function. The utility of each scenario $i-U_{i}$ is calculated as a sum of the products of absolute weights $\mathrm{w}_{\mathrm{a}}$ on the path in the hierarchy tree (from the overall goal, through criteria and sub-criteria) the scenario is associated with. The utility $U_{i}$ represents the contribution of scenario $i$ in reaching an overall goal and constitutes its aggregated appraisal that defines its position in the final ranking.

The important element of the AHP algorithm is the investigation of the consistency level of matrices of relative weights $w_{a}$ on each level of the hierarchy. Through the calculation of a, the so-called consistency index CI one can measure how consistent the preferential information provided by the $\mathrm{DM}$ is. If the value of $\mathrm{CI}$ is close to 0 , the preferential information provided by the DM is considered to be almost perfect. The acceptable level of $C I$ is below 0.1 . The method details described using algorithm flowcharts, formal formulae and equation numbering are presented in the literature by Saaty, T. [21]. 


\section{Construction of scenarios}

Six scenarios (V1, V2, V3, V4, V5, V6) have been constructed as alternative transport solutions for the above-described traffic corridor located in Wroclaw, Poland. The following elements have been taken into consideration in the construction of the scenarios:

- alternative modes of transportation (buses and/or trams),

- different types of vehicles considered (standard or articulated buses, different models of trams and buses),

- various approaches to handling transportation priorities for public transport, such as separate bus lanes or tram tracks, traffic lights controlled by bus or tram drivers, no priorities for public transport - buses and trams moving together with the general traffic (private cars, commercial vehicles),

- location and distribution of bus and tram stops along the traffic corridor; different distances between stops,

- alternative technical solutions applied in the construction of bus lanes and tram tracks (different pavements, alternative types of tramways).

In the public transportation modes analysis, only surface transportation modes have been considered. Metro (underground) has been eliminated from considerations due to the fact that it is not a feasible transportation solution for a metropolitan area inhabited by a smaller number of people than 1 million. Metro construction is very expensive and the generated investment costs are very high. Relatively small passenger flows do not guarantee that the investment costs will be paid back. The analysed scenarios are described below [4].

\section{Scenario 1 - standard city-bus}

In this scenario, a standard city-bus with a maximum capacity of 100 passengers (for example, Solaris Urbino 12 or Mercedes Citaro O530) is introduced as a means of transportation. The optimal capacity in a standard city-bus is 80 . The bus stops are uniformly distributed along the traffic corridor. The average distance between stops is $500 \mathrm{~m}$ (the typical distance beyond the city centre area). The average distance pedestrians walk to the bus stop is $389 \mathrm{~m}$ and it takes them an average of 5.403 minutes. The bus operational speed is $12 \mathrm{~km} / \mathrm{h}$. For a standard city-bus, renewal of the road (width $7 \mathrm{~m}$ ), investment cost (vehicles) and the cost of maintenance are taken into account.

Scenario 2 - articulated bus

In this scenario, the means of transportation is an articulated bus with a maximum capacity of 176 passengers (for example, Solaris Urbino 18 or Mercedes Citaro O530G). The optimal capacity in an articulated bus is 140 . The bus stops are uniformly distributed along the traffic corridor. The average distance between stops is $500 \mathrm{~m}$ (the typical distance beyond the city centre area). The average distance pedestrians walk to the bus stop is $389 \mathrm{~m}$ and it takes them on average of 5.403 minutes. The bus operational speed is $12 \mathrm{~km} / \mathrm{h}$. For articulated buses, renewal of the road (width $7 \mathrm{~m}$ ), investment cost (vehicles) and cost of maintenance are taken into account. 


\section{Scenario 3 - standard city-bus using separate bus lane}

In this scenario, a standard city-bus using a separate bus lane with a maximum capacity of 100 passengers (for example, Solaris Urbino 12 or Mercedes Citaro O530) is introduced as a means of transportation. The optimal capacity in this scenario is the same as scenario 1 and is 80 . The bus stops are uniformly distributed along the traffic corridor. The average distance between stops is $500 \mathrm{~m}$ (the typical distance beyond the city centre area). The average distance pedestrians walk to the bus stop is $389 \mathrm{~m}$ and it takes them on average of 5.403 minutes. The bus operational speed is $18 \mathrm{~km} / \mathrm{h}$ (higher speed applies due to lack of disturbance from traffic and other vehicles). For standard city-buses using a separate bus lane, the building of two bus lanes (width $3.5 \mathrm{~m}$ ), renewal of the road (width $7 \mathrm{~m}$ ), investment cost (vehicles) and the cost of maintenance are taken into account.

\section{Scenario 4 - articulated city-bus using separate bus lane}

In this scenario, an articulated city-bus using a separate bus lane with a maximum capacity of 176 seats (for example, Solaris Urbino 18 or Mercedes Citaro O530G) is introduced as a means of transportation. The optimal capacity in this scenario is the same as scenario 2 and is 140 . The bus stops are uniformly distributed along the traffic corridor. The average distance between stops is $500 \mathrm{~m}$ (the typical distance beyond city centre area). The average distance pedestrians walk to the bus stop is $389 \mathrm{~m}$ and it takes them on average of 5.403 minutes. The bus operational speed is $18 \mathrm{~km} / \mathrm{h}$. For articulated buses using a separate bus lane, the building of two bus lanes (width $3.5 \mathrm{~m}$ ), renewal of the road (width $7 \mathrm{~m}$ ), investment cost (vehicles) and cost of maintenance were taken into account.

\section{Scenario 5 - traditional tram}

In this scenario, a traditional tram with a maximum capacity of 250 seats (for example, Moderus Beta tramway in Wroclaw or Poznan) is introduced as a means of transportation. The optimal capacity in a traditional tram is 200 . The tramway stops are uniformly distributed along the traffic corridor. The average distance between stops is $500 \mathrm{~m}$ (typical distance beyond city centre area). The average distance pedestrians walk to the tram stop is $389 \mathrm{~m}$ and it takes them on average of 5.403 minutes. The tramway operational speed is $18 \mathrm{~km} / \mathrm{h}$. The tram uses a track set into the road for half the route, while for the second half, the tram uses a separate track. For a traditional tram, which uses the road for half the route with the rest on a separate track, the building of a separate tram track, renewal of the separate tram track, building of the tram track into road, renewal of the tram track into road, investment cost (vehicles), maintenance of the tram track in the road and maintenance of the road (width $7 \mathrm{~m}$ ) are taken into account.

\section{Scenario 6 - fast tram}

In this scenario, a fast tram with a maximum capacity of 250 seats (for example - Pesa Twist $32 \mathrm{~m}$ long tram in Wroclaw and Silesia or Solaris Tramino tram in Poznan, Olsztyn and planned for Krakow) is introduced as a means of transportation. The optimal capacity in this scenario is the same as scenario 5 and is 200 . The tram stops are uniformly distributed along the traffic 
corridor. The average distance between stops is $700 \mathrm{~m}$ (this has an influence on high speed operation). The average distance pedestrians walk to the fast tram stop is $473 \mathrm{~m}$ and it takes them on average of 6.569 minutes. The tram operational speed is $24 \mathrm{~km} / \mathrm{h}$. The tram uses a separated tramway line over the entire track, with signal lights assuring tram priorities. For a fast tram whose entire journey is on a separate track away from the influence of car traffic, the building of a separate tram track, the renewal of the separate tram track, the building of the tram track into the road, the renewal of tram track into the road, investment cost (vehicles), maintenance of the tram track into the road and maintenance of the road (width $7 \mathrm{~m}$ ) are taken into account.

\section{Appraisal of scenarios}

The scenarios are evaluated by a consistent family of criteria with the application of ELECTRE III/IV and AHP methods. Two different models of decision-maker preferences were created, which is characteristic for these methods. The problem was solved taking into account the passengers' point of view. The results of computational experiments lead to the final rankings of scenarios. The final stage is the comparison of the obtained results - this shows how different solutions can be obtained.

\subsection{Family of criteria}

In order to rate the alternatives, a set of a coherent family of six criteria was proposed. These criteria are as follows:

- Waiting time [minutes] - average time spent by a passenger at a stop; this criterion is determined as a 0.5 interval; minimised criterion,

- Riding time [minutes] - time required to cover the distance of an average trip; this criterion considers the journey distance $-5 \mathrm{~km}$ and operational speed (this depends on the means of transport); minimised criterion,

- Accessibility to the stop [minutes] - time the passenger needs to reach the bus/tram stop; it is the quotient of walking distance to bus/tram stop and walking speed; walking speed was assumed as $1.2 \mathrm{~m} / \mathrm{s}$; minimised criterion,

- Comfort of travel [\%] - share of seated passengers in maximum number of flow; maximised criterion,

- Cost of rolling stock purchase $[\mathrm{zl} / \mathrm{km} /$ year $]$ - converted cost of rolling stock purchase per one passenger; the cost is dependent on length of corridor and journey distance, accepted discount rate, cost of rolling stock purchase; minimised criterion,

- Cost of building, maintenance and renewal of route [zt/km/year] - converted cost of building, maintenance and renewal of route per one passenger; the criterion depends on the length of corridor, journey distance, passenger flow, unit cost of building and maintenance of routes and accepted discount rate; cost of building, maintenance and renewal is calculated taking into account a discount rate of $6 \%$ for 20 years; the cost was accepted according to actual market values (Table 1.); minimised criterion. 
Table 1. Unit cost (market value) of building, renewal, maintenance and investment (vehicles)

\begin{tabular}{|c|c|c|c|c|c|}
\hline Objects & Unit & $\begin{array}{l}\text { Standard } \\
\text { bus }\end{array}$ & $\begin{array}{c}\text { Articulated } \\
\text { bus }\end{array}$ & $\begin{array}{c}\text { Traditional } \\
\text { tramway }\end{array}$ & Fast tramway \\
\hline Building of separate tram track & {$[\mathrm{zl} / \mathrm{km}]$} & & & $12,000,000$ & $18,000,000$ \\
\hline $\begin{array}{l}\text { Reconstruction of the separate } \\
\text { tram track }\end{array}$ & {$[\mathrm{zl} / \mathrm{km}]$} & & & $8,000,000$ & $12,000,000$ \\
\hline Building of tram track into road & {$[\mathrm{zl} / \mathrm{km}]$} & & & $14,000,000$ & $21,000,000$ \\
\hline $\begin{array}{c}\text { Reconstruction of the tram track } \\
\text { into road }\end{array}$ & {$[\mathrm{zl} / \mathrm{km}]$} & & & $10,000,000$ & $15,000,000$ \\
\hline $\begin{array}{l}\text { Building of two bus lanes } \\
\text { (width } 3.5 \mathrm{~m} \text { ) }\end{array}$ & {$[\mathrm{zl} / \mathrm{km}]$} & $4,000,000$ & $4,000,000$ & & \\
\hline $\begin{array}{l}\text { Reconstruction of the road } \\
\text { (width } 7 \mathrm{~m} \text { ) }\end{array}$ & {$[\mathrm{zl} / \mathrm{km}]$} & $2,000,000$ & $2,000,000$ & & \\
\hline Investment cost (vehicle) & [zt/piece $]$ & $1,150,000$ & $1,550,000$ & $4,300,000$ & $8,970,000$ \\
\hline $\begin{array}{c}\text { Cost of maintenance separate } \\
\text { track of tram }\end{array}$ & {$[\mathrm{zl} / \mathrm{km} /$ year $]$} & & & 52,000 & 62,000 \\
\hline $\begin{array}{c}\text { Cost of maintenance of tram } \\
\text { track into road }\end{array}$ & {$[\mathrm{zl} / \mathrm{km} /$ year $]$} & & & 72,000 & 86,000 \\
\hline $\begin{array}{l}\text { Cost of maintenance of road } \\
\text { (width } 7 \mathrm{~m} \text { ) }\end{array}$ & {$[\mathrm{zl} / \mathrm{km} /$ year $]$} & 24,000 & 24,000 & & \\
\hline
\end{tabular}

The calculations exclude the running costs of vehicles, assuming that this cost will on the whole be covered by revenue from sales of tickets. The main characteristic value for each criterion and direction of preferences are described in Table 2.

Table 2. Characteristic parameters of scenarios

\begin{tabular}{|c|c|c|c|c|c|c|c|c|}
\hline & \multirow{2}{*}{ Criterion } & \multirow{2}{*}{$\begin{array}{l}\text { Direction of } \\
\text { preferences }\end{array}$} & \multicolumn{6}{|c|}{$\begin{array}{l}\text { Average journey distance } 5 \mathrm{~km} \\
\text { Max. number of flow } 20,000\end{array}$} \\
\hline & & & V1 & V2 & V3 & V4 & V5 & V6 \\
\hline $\mathrm{C} 1$ & Waiting time & Min & 1.2 & 2.1 & 1.2 & 2.1 & 3 & 3 \\
\hline $\mathrm{C} 2$ & Riding time & Min & 25 & 25 & 16.66 & 16.66 & 16.66 & 12.5 \\
\hline $\mathrm{C} 3$ & Accessibility of stop & Min & 5.403 & 5.403 & 5.403 & 5.403 & 5.403 & 6.569 \\
\hline $\mathrm{C} 4$ & Comfort of travel & Max & 0.155 & 0.22 & 0.155 & 0.155 & 0.1 & 0.345 \\
\hline $\mathrm{C} 5$ & $\begin{array}{l}\text { Cost of vehicles } \\
\text { purchase }\end{array}$ & Min & 0.302 & 0.216 & 0.201 & 0.146 & 0.256 & 0.317 \\
\hline C6 & $\begin{array}{l}\text { Cost of building, } \\
\text { maintenance and } \\
\text { renewal of route }\end{array}$ & Min & 0.013 & 0.013 & 0.255 & 0.255 & 0.323 & 0.354 \\
\hline
\end{tabular}




\subsection{Modelling of the decision-making preferences}

The ELECTRE III/ IV and AHP methods, which were described in section two, were applied for assessment. The problem was solved by experts taking into account preferences of the passenger and operator. The ELECTRE III/IV method utilises a preference model based on weights of criteria $-w$ and thresholds $q, p$ and $v$. These thresholds represent the sensitivity of the DM to the changes in criteria values. All four values $-w, q, p$ and $v$ are defined separately for each criterion. The model of the DM's preference characteristic for the ELECTRE III/IV method is presented in Table 3.

Table 3. The DM's preference characteristic model for the ELECTRE III/IV method

\begin{tabular}{|c|c|c|c|c|c|c|c|c|c|c|c|}
\hline \multirow{2}{*}{\multicolumn{3}{|c|}{ Criterion }} & \multirow{3}{*}{$\begin{array}{c}\begin{array}{c}\text { Direction of } \\
\text { preferences }\end{array} \\
\text { Min }\end{array}$} & \multicolumn{4}{|c|}{ Passenger } & \multicolumn{4}{|c|}{ Operator } \\
\hline & & & & \multirow{2}{*}{$\begin{array}{c}w \\
10\end{array}$} & \multirow{2}{*}{$\begin{array}{c}q \\
0.5\end{array}$} & \multirow{2}{*}{$\begin{array}{l}p \\
1\end{array}$} & \multirow{2}{*}{$\begin{array}{l}v \\
2\end{array}$} & \multirow{2}{*}{$\begin{array}{l}w \\
3\end{array}$} & \multirow{2}{*}{$\begin{array}{l}q \\
1\end{array}$} & \multirow{2}{*}{$\begin{array}{l}p \\
3\end{array}$} & \multirow{2}{*}{$\begin{array}{l}v \\
5\end{array}$} \\
\hline $\mathrm{C} 1$ & Waiting time & {$[\mathrm{min}]$} & & & & & & & & & \\
\hline $\mathrm{C} 2$ & Riding time & {$[\mathrm{min}]$} & Min & 6 & 2.5 & 3 & 5 & 8 & 3 & 15 & 20 \\
\hline $\mathrm{C} 3$ & $\begin{array}{c}\text { Accessibility of } \\
\text { stop }\end{array}$ & [min] & Min & 8 & 2.5 & 3 & 4.5 & 4 & 0.5 & 2 & 6 \\
\hline $\mathrm{C} 4$ & Comfort of travel & [\%] & Max & 5 & 0.05 & 0.1 & 0.3 & 6 & 0.05 & 0.1 & 2 \\
\hline $\mathrm{C} 5$ & Cost of purchase & [zl/pas] & Min & 1 & 0.05 & 0.2 & 0.8 & 10 & 0.05 & 0.3 & 4 \\
\hline C6 & $\begin{array}{c}\text { Cost of building, } \\
\text { maintenance and } \\
\text { renewal route }\end{array}$ & {$[\mathrm{zl} / \mathrm{pas}]$} & Min & 1 & 0.01 & 0.1 & 0.25 & 2 & 0.15 & 0.25 & 0.1 \\
\hline
\end{tabular}

As a result of the computational experiments, two different models of the DM's preferences were obtained - a graphical (final graph) and a numerical form (ranking matrix) - which take into consideration the relations: $\mathrm{I}$ - indifference, $\mathrm{P}$ - preference, $\mathrm{P}^{*}$ - lack of preference and incomparability - R. The results of the experiments carried out by the ELECTRE III/IV method are presented in Figs 1 \& 2 .

The results obtained from the ELECTRE III/IV method show that the best solution from the passenger viewpoint is scenario V3 (standard city-bus using a separate bus lane) and from the operator viewpoint, it is scenario V4 (articulated city-bus using a separate bus lane).

In the AHP method, the model of the DM's preferences is based on the relative weights representing the strengths of particular elements in the pair-wise comparison of criteria and scenarios described in section 2. In the AHP method, the final ranking is based on the computation of the utility function of each scenario. Tables 4 and 5 show the model of DM preferences characteristic of the AHP method for two different DM model preferences. 


\section{盘Ranking Matrix}

\begin{tabular}{c|c|c|c|c|c|c|}
\hline \multirow{2}{*}{ V1 } & V1 & V2 & V3 & V4 & V5 & V6 \\
\cline { 2 - 7 } V2 & $\mathbf{I}$ & $\mathbf{P}$ & $\mathbf{P}^{-}$ & $\mathbf{I}$ & $\mathbf{P}$ & $\mathbf{P}^{-}$ \\
\cline { 2 - 7 } V3 & $\mathbf{P}$ & $\mathbf{I}$ & $\mathbf{P}^{-}$ & $\mathbf{P}^{-}$ & $\mathbf{P}$ & $\mathbf{P}^{-}$ \\
\cline { 2 - 7 } V4 & $\mathbf{P}$ & $\mathbf{P}$ & $\mathbf{P}^{-}$ & $\mathbf{I}$ & $\mathbf{P}$ & $\mathbf{P}^{-}$ \\
\cline { 2 - 7 } V5 & $\mathbf{P}^{-}$ & $\mathbf{P}^{-}$ & $\mathbf{P}^{-}$ & $\mathbf{P}^{-}$ & $\mathbf{I}$ & $\mathbf{P}^{-}$ \\
\cline { 2 - 7 } v6 & $\mathbf{P}$ & $\mathbf{P}$ & $\mathbf{P}^{-}$ & $\mathbf{P}$ & $\mathbf{P}$ & $\mathbf{I}$ \\
\cline { 2 - 7 }
\end{tabular}

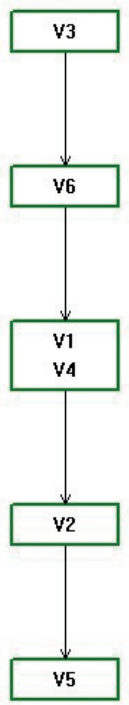

Fig. 1. Graphical results of computational experiments

- passenger preference

\begin{tabular}{|c|c|c|c|c|c|c|}
\hline \multicolumn{7}{|c|}{ 為Ranking Matris } \\
\hline$>$ & V1 & v2 & v3 & $\mathrm{V} 4$ & v5 & v6 \\
\hline $\mathrm{V} 1$ & I & $\mathbf{P}^{-}$ & $\mathbf{P}^{-}$ & $\mathbf{P}^{-}$ & $\mathbf{P}^{-}$ & $\mathbf{P}^{-}$ \\
\hline V2 & $\mathbf{P}$ & I & $\mathbf{P}^{-}$ & $\mathbf{P}^{-}$ & $\mathbf{P}^{-}$ & $\mathbf{P}^{-}$ \\
\hline v3 & $\mathbf{P}$ & $\mathbf{P}$ & I & $\mathbf{P}^{-}$ & I & $\mathbf{P}^{-}$ \\
\hline V4 & $\mathbf{P}$ & $\mathbf{P}$ & $\mathbf{P}$ & I & $\mathbf{P}$ & $\mathbf{P}$ \\
\hline v5 & $\mathbf{P}$ & $\mathbf{P}$ & I & $\mathbf{P}^{-}$ & I & $\mathbf{P}^{-}$ \\
\hline V6 & $\mathbf{P}$ & $\mathbf{P}$ & $\mathbf{P}$ & $\mathbf{P}^{-}$ & $\mathbf{P}$ & $\mathbf{I}$ \\
\hline
\end{tabular}

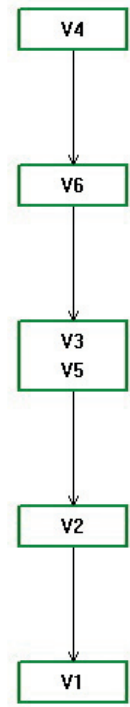

Fig. 2. Graphical results of computational experiments - operator preference

Table 4. The model of DM preferences characteristic of the AHP method, comparison of criteria - passenger preference

\begin{tabular}{|c|c|c|c|c|c|c|}
\hline & $\mathrm{C} 1$ & $\mathrm{C} 2$ & $\mathrm{C} 3$ & $\mathrm{C} 4$ & $\mathrm{C} 5$ & $\mathrm{C} 6$ \\
\hline $\mathrm{C} 1$ & 1 & 3 & 2 & 4 & 7 & 7 \\
\hline $\mathrm{C} 2$ & $1 / 3$ & 1 & $1 / 2$ & 1 & 4 & 4 \\
\hline $\mathrm{C} 3$ & $1 / 4$ & 2 & 1 & 2 & 5 & 5 \\
\hline $\mathrm{C} 4$ & $1 / 4$ & 1 & $1 / 2$ & 1 & 3 & 3 \\
\hline $\mathrm{C} 5$ & $1 / 7$ & $1 / 4$ & $1 / 5$ & $1 / 3$ & 1 & 1 \\
\hline $\mathrm{C} 6$ & $1 / 7$ & $1 / 4$ & $1 / 5$ & $1 / 3$ & 1 & 1 \\
\hline
\end{tabular}


Table 5. The model of DM preferences characteristic of the AHP method, comparison of criteria - operator preference

\begin{tabular}{|c|c|c|c|c|c|c|}
\hline & $\mathrm{C} 1$ & $\mathrm{C} 2$ & $\mathrm{C} 3$ & $\mathrm{C} 4$ & $\mathrm{C} 5$ & $\mathrm{C} 6$ \\
\hline $\mathrm{C} 1$ & 1 & $1 / 5$ & $1 / 2$ & $1 / 3$ & $1 / 7$ & 2 \\
\hline $\mathrm{C} 2$ & 5 & 1 & 4 & 2 & $1 / 2$ & 7 \\
\hline $\mathrm{C} 3$ & 2 & $1 / 4$ & 1 & $1 / 2$ & $1 / 5$ & 2 \\
\hline $\mathrm{C} 4$ & 3 & $1 / 2$ & 2 & 1 & $1 / 3$ & 3 \\
\hline $\mathrm{C} 5$ & 7 & 2 & 3 & 3 & 1 & 7 \\
\hline $\mathrm{C} 6$ & $1 / 2$ & $1 / 7$ & $1 / 2$ & $1 / 3$ & $1 / 7$ & 1 \\
\hline
\end{tabular}

The graphical results of computational experiments carried out by the AHP method are presented in Figs 3 \& 4.

$$
\begin{aligned}
& \text { 0,207:-V3 } \\
& 0,188 \text { : - V1 } \\
& 0,167 \text { : - V4 } \\
& 0,164 \text { : - V6 } \\
& 0,155:-V 2 \\
& 0,120 \text { : - V5 }
\end{aligned}
$$

Fig. 3. Graphical results of computational experiments - passenger preference
$0,258:-V_{4}$
0,$191 ;-\vee 6$
$0,182:-\sqrt{ } 3$
$0,146:-\vee 2$
$0,129:-\vee 5$
$0,094:-\vee 1$

Fig. 4. Graphical results of computational experiments - operator preference

The values of the utility function for scenarios counted by the AHP method are aggregated values which show the positions of individual scenarios in the final ranking. The value enables the description of the distances between the individual scenarios - this is not possible in the ELECTRE III/IV method. The best solution, taking passengers' needs into consideration, is scenario 3 (standard city bus using a separate bus lane); however, taking into consideration the operator's view of point, the best solution is scenario 4 (articulated city bus using a separate bus lane) in both the AHP and the ELECTRE III/IV method.

\section{Summary and conclusion}

The paper presents the application of a multi-criteria method of appraising public transport. Various means of transport along a $15 \mathrm{~km}$ transportation corridor were evaluated. The experiments were carried out using computer implementations of the ELECTRE III/ IV and AHP methods taking into account two models of DM preference: passenger and operator. In the first case (ELECTRE III/IV), the final generated ranking was based on the calculation of the outranking relation, while the second experiment (AHP) was based on the computation of the utility function of each scenario. 
Six scenarios were created. First, some scenarios concerning the means of transport using the transportation corridor were created. Next, the consistent family of criteria that assures the comprehensive appraisal of scenarios was defined. The DM's model of preferences then was created, and in the last step, the problem was solved by special software for multicriterion assessment (AHP, Electre III/IV). Taking into account passenger preferences, the best scenario is V3 (standard city-bus using a separate bus lane) and the worst scenario is V5 (traditional tram) according to both the AHP and the ELECTRE III/IV methods. Taking into account operator preferences, the best scenario is V4 (standard city-bus using a separate bus lane and fast tram) and the worst scenario is V1 (standard city-bus) according to both the ELECTRE III/IV and the AHP methods. Despite the use of two different MCDM methods, the results obtained are quite similar. This article shows the different functionality of the modes of transport from both the passengers and the operators perspective. The results are somewhat different for operators and passengers because they have different preferences. Some criteria are more important for the passenger (waiting time, accessibility to the bus stop) and some criteria are more important for the operator (cost of purchase). The results of the abovedescribed analysis extend the knowledge on real cases of selection of transportation scenarios and can be used in the practice of decision making by local governments in Polish cities.

\section{References}

[1] BransJ.,MareschalB.,VinckeP., Promethee.A newfamily ofoutrankingmethodsin multicriteria analysis, Brans J. (ed.) Operations Research '84, North-Holland, Amsterdam1984.

[2] Cascetta N., Transportation system engineering: theory and methods, Kluwer Academic Publishers, London 2001.

[3] Daganzo C., Fundamentals of transportation and traffic operations, Pergamon Press, San Francisco 1997.

[4] Dudek M., Rudnicki A., Optymalizacja obstugi pasma zabudowy transportem zbiorowym, Warszawa 2007.

[5] Ernst \& Young / Politechnika Krakowska, Plan Generalny rozwoju transportu szynowego we Wrocławiu. Część 1: Ogólna koncepcja transportu szynowego we Wrocławiu, 2007.

[6] Geoffrion A., Dyer J., Feinberg A., An interactive approach for multi-criterion optimization, with an application to the operation of an academic department, Management Science, Vol. 19, No.4, 1972.

[7] Gupta A., Comparative study of private and public bus transport in Delhi, Proceedings of the 8th IFAC Symposium on Transportation Systems, Chania 1997.

[8] Haimes Y. Y., Hall W. A., Multiobjectives in water resources systems analysis: The SWT method, Water Resources Research, Vol. 10/1975.

[9] Jacquet-Lagreze E., Siskos J., Assessing a set of additive utility functions for multicriteria decision making: the UTA method, European Journal of Operational Research, Vol. 10/1982.

[10] Keeney R., Raiffa H., Decisions with multiple objectives. Preferences and value tradeoffs, Cambridge University Press, Cambridge 1993. 
[11] Kiba Janiak M., Żak J., Multiple Criteria Evaluation of Different Redesign Scenarios of the Public Tram System, Transportation Research Procedia, Vol. 3/2014.

[12] Kiciński M., Judt W., Kłosowiak R., Wielokryterialna ocena wariantów dojazdu mieszkańców aglomeracji poznańskiej do Poznania, Autobusy, Technika, Eksploatacja, Systemy Transportowe, vol. 12, 2017, 560-563.

[13] Kobryń A., Wielokryterialne wspomaganie decyzji w gospodarowaniu przestrzenia, Warszawa 2014.

[14] Litman, T., Well measured-developing indicators for sustainable and livable Public transport planning, Victoria Transport Policy Institute, Victoria, Canada, http://www.vtpi.org/ wellmeas.pdf (access: 10.01.2018).

[15] Macharis C., Bernardini A., Reviewing the use of Multi-Criteria Decision Analysis for the evaluation of transport projects: Time for a multi-actor approach, Transport Policy Vol. 37 / 2015, 177-186.

[16] Owczarzak Ł., ŻakJ., Design of passenger public transportation solutions based on autonomous vehicles and their multiple criteria comparison with traditional forms of passenger transportation, 18th Euro Working Group on Transportation, EWGT 2015, 14-16 July 2015, Delft, The Netherlands, Transportation Research Procedia, Vol. 10/2015, 472-482.

[17] Pastijn H., Leysen J., Constructing an outranking relation with ORESTE, Mathematical and Computer Modelling, Vol. 12, No 10/11, 1989.

[18] Roy B., The outranking approach and the foundations of Electre methods, [in]: Bana e Costa C. (Ed.), Readings in Multiple Criteria Decision Aid, Springer-Verlag, Berlin 1990.

[19] Roy B., Wielokryterialne wspomaganie decyzji, Wydawnictwo Naukowo-Techniczne, Warszawa 1990.

[20] Rudnicki, A., Jakość komunikacji miejskiej, SITK, Krakow 1999.

[21] Saaty, T., The Analytic Hierarchy Process: Planning, priority setting, resource allocation, McGraw-Hill, New York 1980.

[22] Saaty T., Transport planning with multiple criteria: The Analytic Hierarchy Process applications and progress review, Journal of Advanced Transportation, Vol. 29, No. 1, 1995.

[23] Sawicki P., Kiciński M., Fierek S., Selection of the most adequate trip-modelling tool for integrated transport planning system, Archives of Transport, 2016, Vol. 37, Iss. 1, 2016, 55-66.

[24] Skalka, J., Bouyssou, D., Bernabeu, Y., ELECTRE III et IV. Aspects methodologiques et guide d'utilisation, LAMSADE, 25, Paris 1986.

[25] Solecka K., Wielokryterialna ocena wariantów zintegrowanego miejskiego transportu publicznego w Krakowie, praca doktorska, Kraków 2013.

[26] Steuer R., An interactive multiple objective linear programming procedure' TIMS studies in the management sciences, Computers \& Operations Research, 1977.

[27] Vincke P., Multicriteria decision-aid, John Wiley\&Sons, Chichester 1992.

[28] Vuchic V., Urban transit systems and technology, John Wiley \& Sons, New York 2007.

[29] Żak J., Fierek S., Design and evaluation of alternative solutions for integrated urban transportation system, CD - Proceedings of the World Conference on Transport Research, Berkeley 2007. 